\title{
Adult Botryoid-Type Embryonal Rhabdomyosarcoma
}

National Cancer Institute

\section{Source}

National Cancer Institute. Adult Botryoid-Type Embryonal Rhabdomyosarcoma. NCI

Thesaurus. Code C36099.

A morphologic variant of embryonal rhabdomyosarcoma occurring in adults. The neoplasm arises from organs containing a mucosal epithelial surface. It is characterized by the formation of a cambium layer in the affected tissue and polypoid nodules with an abundant myxoid stroma. 